\title{
Učitel-profesionál jako písař Bartleby? Raděj ne! Syndrom vyhoření v učitelské profesi Helena Zbudilová
}

"Já bych prosím raděj - ne“.

H. Melville, Písar Bartleby (1856)

Úvodní př́iběh z Wall Streetu nás ve spojitosti s aktuálním tématem časopisu Caritas et Veritas povede $\mathrm{k}$ hlubšímu zamyšlení nad učitelskou profesí a jejím ohrožením syndromem vyhoření. Budeme se zabývat soudobým vnímáním učitelství jako konvergencí zaměstnání, povolání, poslání a profese; učitelem jako dělníkem, řemeslníkem či umělcem a reflektujícím profesionálem, výzkumníkem a expertem zároveň. Zamyslíme se také nad aktuálním postavením učitelské profese v 21. století a dosud nedostatečně prozkoumaným fenoménem syndromu vyhoření u učitelů. Nabídneme tři kazuistiky dokládající závažnost výskytu této psychosomatické poruchy, psychického „infarktu“ jedince postmoderní doby, jak jej výstižně označil současný německy píšící filozof Byung-Chui Han. ${ }^{1}$

\section{Úvod}

Slova úvodního motta, vyjadřující pasivní rezistenci jedince, odkazují na smutný lidský úděl písaře Bartlebyho, který v polovině 19. století představil americký spisovatel Henry Melville. Tragický životní příběh zvláštního protagonisty - antihrdiny, nižšího úředníka, který je zprvu neuvěřitelně pracovně výkonný a spolehlivý, avšak zároveň tajemný, bez přátel, žijící v úplné samotě, neškodný, nekomunikativní, až téměř tichý, vždy př́tomný a jakoby vržený do prostoru u pusté zdi kanceláře, nabízí řadu interpretací: „Pracoval od rána do večera, opisoval za denního světla a opisoval při svíčce. Byl by mě ten zápal těšil, kdyby bývala jeho píle jaksi radostnější, ale on psal tiše, s bledou nehybnou tváŕí, mechanicky“.2 Jednoho dne nastane zvrat v jeho chování. Je požádán o další pracovní úkon, ten ale odmítne. Postupně odmítá vše, skončí ve vězení, kde cíleně umírá ve své samotě u vysoké studené zdi. Jsme svědky toho, jak v jeho prochřadlém těle postupně vyhasíná život, o čemž svědčí jeho otevřené šedé oči „s pohaslým klidem“.3 Interpretací př́běhu se nabízí mnoho. Překladatel R. Nenadál např́ílad zmiňuje téma problému lidské komunikace, pocitu odcizení ve společnosti, tragédie neangažovanosti nebo averze vůči angažovanosti, tragédie pasivity, nechuti konformovat se a přijmout modely společnosti, či negace společnosti

Srov. Byung-Chui HAN, Vyhořelá společnost, Praha: Rybka Publishers, 2016, s. 17.

2 Herman MELVILLE, Písař Bartleby. Př́běh $z$ Wall Streetu. Z ang. originálu Bartleby the Scrivener (Stories of the American Experience) přeložil a doslov napsal Radoslav Nenadál, Praha: Odeon, 1990, s. 27. 
a volbu sebedestrukce. ${ }^{4}$ Nás na př́běhu abulického úředníka zaujal celkový pocit marnosti, kterým trpěla jeho duše. Pocit marnosti z profesního života, pocit marnosti z života osobního. V rovině profesní byl pravděpodobně zcela demotivován prací s nedoručenými „mrtvými“ dopisy, které třídil ke spálení; v rovině osobní byl zcela osamocený, až znehybněný v životě přítomnosti. Přestože byl příběh napsán před více než pưldruhým stoletím, anticipuje v mnohém současného jedince 21. století, který má problém se syndromem vyhoření. Při bližším pohledu na postavu Bartlebyho zjištujeme, že má typické příznaky burnoutu - jedná se o pocity fyzického, emočního i psychického vyčerpání. Je viditelně unavený, emocionálně vyhaslý, působí nemocně, jakoby v tísni, beznaději a depresi, bez chuti do života, chycený do pasti, depersonalizovaný, zahořklý, čiší z něj marnost vlastní existence, nulová sebedůvěra a postupně se snižuje jeho pracovní výkonnost až téměř na nulu.

Bartleby nekomunikuje s okolím, není schopen vnímat ani sám sebe, o vztahu k svému vlastnímu stř̌edu ani nemluvě. Ztrácí smysl všeho. M. D. Rush a D. Heczko využívají k výkladu syndromu vyhoření biblickou postavu proroka Eliáše a onemocnění označují jako „Eliášův syndrom“. ${ }^{5}$ Biblický text uvádí: „Sám šel den cesty pouští, až přišel k jednomu trnitému keři a usedl pod ním; přál si umřít. Řekl: ‘Už dost, Hospodine, vezmi si můj život, vždyt’ nejsem lepší než moji otcové' (1 Kr 19,4). Bůh staví před Eliáše další poslání, potvrzuje důležitost a hodnotu jeho života a osvobozuje ho od úzkosti. Eliáš dokázal překonat svá traumata a očistit svou důvěru v Boha. ${ }^{6}$ Ztroskotals? Máš šanci - taková je biblická odpověd. Je potřeba vystoupit z roli oběti.

Jak dokládá případ písaře Bartlebyho i proroka Eliáše, původní silně hořící oheň, symbolizovaný v psychologické rovině vysokou motivací, zájmem, aktivitou a nasazením, přechází u člověka postiženého syndromem vyhoření do dohořívání a vyhaslosti. Není již k dispozici materiál, který by hořící oheň živil. ${ }^{7}$ To vidíme na literární paralele písaře Bartlebyho. U proroka Eliáše vidíme však pravý opak. A. Grün přináší v knize Vyhoření: Jak rozproudit vlastní energii léčivý biblický obraz vnitřního ohně jako jednu z možných terapií:

„V klidu se posad’te, zavřete oči a vydejte se na dno své duše. Tam se cítíte vyhořelý. Tam se nachází jen samý popel. Jděte však hlouběji. Představte si, že pod tímto popelem se stále ještě nacházejí žhnoucí uhlíky. Představte si, že je rozdmýcháte, načež začnou opět sálat a nakonec se rozhoří. Pod popelem, který v nás dřímá, se nachází žár. Nazývám jej žárem Ducha svatého. Je v každém z nás, at chceme nebo nechceme. ${ }^{\text {8 }}$

V jakém smyslu se proměnily kulisy světa 3. tisíciletí, rodícího následovníky písaře Bartlebyho? Společnost aktuálně prožívané postmoderní situace a rostoucí globalizace je orientována na výkon. Imperativ výkonnosti se stal novým přikázáním dnešní společnosti práce. Vedle kultu výkonnosti se prosazuje kult zisku, kariéry, hybrid pracovitosti a kariérního vzestupu, prestiže a zábavy. Vzrůstá životní tempo. Člověk se zahlušuje prací a zábavou, utíká sám před sebou. Zátěž a stres se stává přirozenou součástí života. Bytí se proměnilo v dění - „začarovaný kruh práce, užívání a spotřebovávání“. Jedinou neotřesitelnou hodnotou ve světě postmoderního relativismu zůstává trh. Informačně přesycená společnost usiluje o status znalostní společnosti. Není divu, že

Srov. Radoslav NENADÁL, Doslov. Tamtéž, s. 107-109.

5 Srov. Daniel HECZKO, Už nemohu dál: o syndromu vyhoření, Třinec: Biblos, 2000, s. 14; Myron D. RUSH, Syndrom vyhoření, Praha: Návrat domů, 2003, s. 48.

Srov. Jana ŘEZBOVÁ, Syndrom vyhoření u kněží (diplomová práce), České Budějovice: TF JU, 2007, s. 57.

Srov. Zuzana PAPÍKOVÁ, Syndrom vyhoření: Rizikové faktory jeho vzniku (diplomová práce), Praha: FF UK, 2013, s. 6.

Srov. Anselm GRÜN, Vyhoření: Jak rozproudit vlastní energii, Praha: Portál, 2014, s. 115. 
syndrom vyhoření roztahuje své sítě v podobě dominantní choroby 21 . století. Je to tichý nepřítel, doprovázející své oběti zprvu jako neviditelný stín, aby postupně vysál veškeré energetické zdroje člověka až k úplnému vyhasnutí jeho životního ohně. Obět je poté vržena do spárů sociální smrti.

\section{Syndrom vyhoření učitelů}

V soudobé společnosti výkonu jsou jedinci nazíráni především jako subjekty výkonnosti. I když máme před sebou téměř neomezené možnosti realizace, paradoxně ztrácíme svou svobodu a suverenitu a můžeme se skutečně dostat do pozice především a pouze pracujícího člověka (animal laborans). Filozof Han definuje tento typ člověka nového tisíciletí, který je přesycený podněty, informacemi a impulsy; žije ve vleku tzv. neuronálního násilí; je vyčerpaný egoista, hyperpozorný, hyperaktivní, hyperneurotický a unavený; vykořistuje sám sebe jako predátor a kořist zároveň; dává energii do toho, aby byl tím, čím je; a oslabuje své sociální vazby. ${ }^{9}$ Od přemíry podnětů, byt pozitivních, $v$ jedné oblasti je již krůček k rozvinutí syndromu vyhoření.

Syndrom vyhoření je odborný termín, který se objevil v psychologii a psychoterapii v 70. letech 20. století. Poprvé jej použil Hendrich Freudenberger. ${ }^{10}$ Označuje psychosomatickél1 stavy vyčerpání, které souvisejí především s profesemi, jejichž náplní je služba druhým lidem. Pomáhající profese jsou rozmanité (lékaři, zdravotní sestry, sociální pracovníci, pedagogové, psychologové...) a jsou z hlediska mezilidských vztahů a psychické zátěže chápány jako povolání riziková. Důsledky přezírání syndromu mohou být zásadní nejen pro jedince, ale i pro celou společnost. Jde o složitý multifaktoriálně podmíněný fenomén, který podle našeho názoru není současnou společností plně vnímán a reflektován, přitom přináší negativní jevy, např. vyčerpanost pracovníků, zdravotní a psychické potíže, zvýšenou nemocnost, odchody mimo profesi, odchody do předčasného důchodu. Syndrom je u nás doposud chápán spíše jako záležitost jedince, jeho osobní selhání či vyčerpání. Odhlíží se od systémové roviny. Ke zlepšení situace snad přispěje okolnost, že české MPSV uvažuje $\mathrm{v}$ současnosti o tom, že by byl syndrom vyhoření zařazen mezi nemoci z povolání. Francouzské ministerstvo práce a sociálních věcí aktuálně změnilo zákoník, protože syndrom vyhoření se zde v roce 2016 týkal 3,2 miliónu Francouzů, kteří byli podle lékařských statistik na pokraji pracovního vyhoření. ${ }^{12}$

Syndrom vyhoření není dosud zařazen mezi nemoci. Podle současné Mezinárodní klasifikace nemocí (MKN 10) není primární diagnózou, ale tzv. diagnózou doplňkovou, která může být přiřazena $\mathrm{k}$ některé $\mathrm{z}$ primárních diagnóz (např. $\mathrm{k}$ depresi). Projevy syndromu vyhoření však můžeme nalézt u 20-30 \% lidí, kteří v práci přicházejí do kontaktu s dalšími lidmi. ${ }^{13}$

V České republice existuje o syndromu vyhoření řada odborných prací, populárně naučných titulů, bakalářských či diplomových prací, které prokazují, že toto téma je vysoce aktuální. Pokud se podíváme do databáze EBSCO, nalezneme zde od 90. let minulého století do současnosti 27127 studií o syndromu vyhoření a česká databáze závěrečných kvalifikačních prací obsahuje o syndromu vyhoření u učitelů cca 900 odkazů. Témata bakalářských a diplomových prací1 ${ }^{14}$ pojednávají

9 Srov. HAN, Vyhořelá..., s. 12-16; s. 27.

10 Srov. Jaro KŘIVOHLAVÝ, Hořet, ale nevyhořet, Kostelní Vydř́: Karmelitánské nakladatelství, 2012, s. 58.

11 Marie TĚTHALOVÁ, To, jak žijeme, máme ve svých rukou. Rozhovor s MUDr. Olgou Kunertovou, Informatorium 6/2017, s. 7.

12 Srov. () Jana ŠAFAŘÍKOVÁ, Budou mít Francouzi právo se po práci „odpojit“?, Mladá Fronta Dnes, 18. 2. 2016 (on-line), dostupné na: http://www.pressreader.com/czech-republic/mf-dnes/20160218/, aktualizace dne 18. 2. 2016, citováno dne 15. 6. 2017; ( ) Markéta MIKEŠOVÁ, Francouzi dostali právo být offline. Novela zákoníku práce umožňuje ignorovat emaily a vypnout mobil, dostupné na: https://www.zive.cz/bleskovky/francouzi-dostali-pravo-byt-offline-novela-zakoniku-prace-umoznuje-ignorovat-emaily-a-vypnoutmobil/sc-4-a-185455/default.aspx, citováno dne 2. 1. 2017.

13 Srov. nap̌r. Zuzana DAŇKOVÁ, Hořet a nevyhořet, Psychologie Dnes, únor 2017, s. 56-57.

14 Např. Kateřina SLANINOVÁ, Syndrom vyhoření u učiteli̊ (diplomová práce), Ostava: PF OU, 2016; Irena BOBYLEVA, Syndrom vyhořeni 
nejčastěji o výskytu syndromu vyhoření na základních a středních školách, ale nalezneme také řadu prací věnovaných dané problematice $\mathrm{v}$ předškolním vzdělávání a vzácně také $\mathrm{v}$ prostředí vysokoškolském. Obecně převažují práce o vymezení syndromu vyhoření (vůči stresu a depresím) a zjištují míru vyhoření v dané profesní kategorii na určitém typu škol, či v rámci jedné školy. Vyskytují se práce věnované popisu vysvětlujících, facilitujících a protektivních faktorů vyhoření. Syndrom vyhoření je zařazen do Pedagogického slovníku, kde je pojímán jako krajní důsledek dlouhodobého psychického tlaku a časové i fyzické zátěže v učitelské práci profesního vyhasínání, kde je takto označován výsledný stav. J. Průcha zmiňuje, že

„V zahraničí i v českém nebo slovenském prostředí jsou diagnostikovány poměrně vysoké hodnoty stupně vyhoření učitelů. Jako nejrizikovější se jeví emoční oblast. Přesto se ukazuje, že psychické vyhoření není v učitelství obecně vyšší než v jiných, na komunikaci a vztah s klienty náročných pomáhajících povoláních“. ${ }^{15}$

První profesní skupinou, na kterou se v českém prostředí zaměřil odborný výzkum formou celonárodní studie o depresi, byli lékaři. Tým 1. lékařské fakulty UK provedl šetření zatíženosti lékařské profese syndromem vyhoření před dvěma roky. Prokázalo se, že znaky syndromu vyhoření vykazuje zhruba třetina doktorů. R. Ptáček, docent 1. lékařské fakulty, poukazuje na zahraniční studie, které dospěly k závěrům, že v několika dalších zemích včetně Spojených států je toto číslo mnohem vyšší. ${ }^{16}$ Šetření přineslo zajímavé zjištění, že pro lékaře je z hlediska rozvoje syndromu vyhoření nejrizikovějších prvních pět šest let, nebot' nastupují do profese a věnují se přípravě na atestace, postupem let riziko klesá. U učitelů se předpokládá, že syndromem vyhoření by měl trpět především učitel-expert v předdůchodovém věku, avšak podobný výskyt se dá očekávat také u začínajících učitelů. Ti přicházejí do škol plní elánu, optimismu a nadšení, avšak mnohdy se dostávají do střetu s realitou. To potvrzuje také výzkum W. Hagemanna, který se zabýval výskytem syndromu vyhoření u učitelů v Německu. Potvrdil, že onemocní především učitelé, kteří mají za sebou dvacet a více let praxe, ale onemocnět mohou i učitelé začínající. ${ }^{17}$ Mezi nejčastější zátěžové faktory v německém školství byla uvedena atmosféra v učitelském sboru, kompetentnost vedoucích pracovníků, nedostatek času na odpočinek, relaxační hodnota přestávek ve vyučování, osamění, chybějící supervize; dále také velikost třídy, chování problémových žáků, počet hodin, koordinace pracovních a soukromých povinností, povinnosti mimo vyučování. Učitelé se cítili být přetěžováni prací, pocit’ovali, že nemohou rozvíjet své schopnosti a že jsou ponecháni svému

u učitelů středních škol (bakalářská práce), Brno: MENDELU, 2017; Vlastimil KARAFIÁT, Syndrom vyhoření u učiteli̊ střední odborné školy (bakalářská práce), Praha: ČVUT, 2017; Veronika FILIPOVÁ, Celoživotní vzdělávání jako prevence syndromu vyhoření (diplomová práce), Brno: FF MU, 2017; Michaela KLIMEŠOVÁ, Syndrom vyhoření u učitelư středních škol (diplomová práce), České Budějovice: PF JU, 2016; Dominika BAKLÍKOVÁ, Syndrom vyhoření u středoškolských učitelů (bakalářská práce), Zlín: FHS UTB, 2015; Jaromír BÍLÝ, Syndrom vyhoření u učitelů (diplomová práce), Ostrava: PF OU, 2015; Sandra SVOBODOVÁ, Syndrom vyhoření u učitelů (diplomová práce), Plzeň: PF ZČU, 2015; Kateřina ŠPRINGLOVÁ, Syndrom vyhoření u učitelů mateřských škol (bakalářská práce), Olomouc: PF UP, 2014; Štěpánka HAVLÍČKOVÁ, Syndrom vyhoření pedagogů (bakalářská práce), Praha: UJAK, 2014; Petr KALKANT, Syndrom vyhoření u učitelů na středních školách (bakalářská práce), UUstí nad Labem: PF UJEP, 2014; Jana MIKULECKÁ, Syndrom vyhoření u učitelů (bakalářská práce), Ústí nad Labem: PF UJEP, 2014; Jan BOHÁČ, Syndrom vyhoření a riziko jeho vzniku u učitelů na 2. stupni ZŠ (bakalářská práce), Pardubice: FF UP, 2013; Kamila MACHOVCOVÁ, Syndrom vyhoření u učitelů 2. stupně ZŠ (diplomová práce), České Budějovice: PF JU, 2014; Ilona NESVADBOVÁ, Syndrom vyhoření učitele (bakalářská práce), Olomouc: FF UP, 2013; Jolana ZACHOVÁ, Syndrom vyhoření z pohledu učitelů v praxi a možnosti jeho předcházení (diplomová práce), Brno: PF MU, 2010; Lenka STIBŮRKOVÁ, Syndrom vyhoření v učitelské profesi (diplomová práce), Brno: PF MU, 2007.

15 Jan PRŮCHA (ed.), Pedagogická encyklopedie, Praha: Portál, 2009, s. 406.

16 Srov. Radmil ŠVANCAR, Má vaše práce smysl?, Učitelské noviny 1/2017, s. 20.

17 Srov. Wolfgang HAGEMANN, Syndrom vyhoření u učitelů. Př́činy, pomoc, terapie, Ústí nad Labem: Univerzita Jana Evangelisty Purkyně, 2012, s. 10 . 
osudu. ${ }^{18}$ Střet s realitou výstižně komentuje A. Staněk, autor kvalitativního výzkumu profesní identity učitele výchovy k občanství:

„S nástupem do praxe přichází nejprve šok spojený se vstupem do reality učitelské profese. Tento prvotní šok a následná dvou až třiletá etapa začínajícího učitele znamená především souboj ideálů (prekonceptů) a reality. Veden je jednak v učitelově nitru, jednak i na vnějších bojištích - ve třídách, sborovnách i s rodičovskou veřejností. Rozhodujícími faktory jsou v této profesní fázi vytrvalost, houževnatost a oddanost učitelskému povolání, spojené $\mathrm{s}$ otevřeností $\mathrm{k}$ vnějším podnětům (schopnost naladit se na správnou frekvenci) a tím i připravenost k profesním metamorfózám“.19

Druhou profesní skupinou, jež je u nás aktuálně podrobena celonárodnímu výzkumu, jsou právě učitelé. Na konci roku 2016 byl zahájen výzkum nazvaný „Vyhoření učitelů a učitelek ZŠS“, v němž se prostřednictvím on-line dotazníkového šetření do konce února letošního roku sbírala data od 1000-1500 vyučujících. Tento výzkum řídí Psychiatrická klinika 1. LF UK spolu s Katedrou psychologie PF UK. Ve výzkumu budou zachyceny nejen profesní charakteristiky učitele (jak dlouho, co a kde učí), ale i další osobní údaje o životním stylu, stravovacích návycích, kouření, požívání alkoholu, tělesném pohybu, řešení stresu... Studie má zjistit, zda a do jaké míry je u učitelů rozvinut syndrom vyhoření a jak je zatěžuje profesní únava či deprese. ${ }^{20}$ Výzkum zajisté přinese cenné postřehy, které bude možno implementovat do prevence syndromu vyhoření učitelů. Ten se odvíjí v několika základních fázích a nemusí vždy znamenat, že u jedince propukne naplno. Může se jednat i o vyhoření částečné. Mezi učiteli není dosud zvykem věnovat se supervizi, která nabízí dostatečný prostor pro reflexi vlastní práce, pracovních postupů a vztahů na pracovišti, přináší možnost zastavit se, př̌emýšlet sám i s kolegy zároveň, sdělit si nové nápady a inspirovat se. Využívání individuální, skupinové či týmové supervize, na rozdíl od prostředí sociální práce, není zatím ve školním prostředí běžné. ${ }^{21}$ Různé intervence a způsoby působení proti profesní únavě musí jít také ruku v ruce se změnou životního stylu, vhodným trávením volného času a pozitivními mezilidskými vztahy.

\section{Učitel 21. století - profesionál, osobnost, dělník (učitelská profesní konvergence)}

Jedním z klíčů $\mathrm{k} 21$. století je koncept tzv. učící se společnosti, koncept učení se v průběhu celého života. Vzdělávání v 21. století má být podle Zprávy mezinárodní komise UNESCO Učení jako skryté bohatství: Vzdělávání pro 21. století vystavěno na čtyřech pilírích: učit se poznávat, jednat, žít společně a být. Podle konstatování dokumentu OECD jsou ve znalostní společnosti učitelé klíčovými činiteli ve všech strategických postupech zaměřených na podporu rozvoje společnosti a ekonomiky. ${ }^{22}$ Ve všech modelech kvalitní školy hraje fenomén učitele klíčovou roli. Kvalita učitelů je klíčový faktor, který zásadním způsobem ovlivňuje kvalitu vzdělávání. Charakteristika kvality učitele zahrnuje znalosti, pedagogické a didaktické dovednosti, postoje, hodnoty

18 Tamtéž, s. 11.

19 Antonín STANĚK, Kvalitativní výzkum profesní identity učitele výchovy k občanství, Praha: Epocha, 2010, přebal.

20 Otázky studie viz www.ucitelskevyhoreni.cz

21 Srov. TĚTHALOVÁ, To, jak žijeme..., s. 7.

22 Srov. Zdeněk HELUS - Noemi BRAVENÁ - Marta FRANCLOVÁ, Perspektivy učitelství, Praha: PF UK, 2012 , s. 9. 
a osobnostní vlastnosti. ${ }^{23}$ Klíčovým evropským trendem je podpora profesionalizace učitelství. Za klíčové znaky profese jsou považovány existence profesních/expertních znalostí, smysl pro službu veřejnosti, celoživotní angažovanost a oddanost práci se žáky. ${ }^{24}$ Učitel musí být profesním odborníkem. Současně však svoji profesionalitu přesahuje. ${ }^{25}$ Podle Zdeňka Heluse se profesionalita učitele zakládá na jeho znalostech, dovednostech a kompetencích. Sociologové často vřazují učitelství do kategorie tzv. semi-profesí (polo-profesí). Mezi důvody uváděnými na obhajobu tohoto zařazení patří např. následující tvrzení: práce je vykonávána ve velkých hierarchických byrokratických organizacích podléhajících administrativní (nikoli profesní) autoritě, velké množství vykonavatelů práce aj. ${ }^{26}$

Pojem povolání odkazuje na učitelovu osobnost a její morální ukotvení. Učitelství jako povolání, respektive poslání (v kontrapozici k pouhému zaměstnání) akcentuje osobnost a její pedagogické ctnosti. Opírá se o tezi, že učitel se svými osobnostními kvalitami, tím, kým je, jak jedná, co ztělesňuje, je žákovi nejúčinnějším podnětem $\mathrm{k}$ tomu, aby se on sám jako osobnost rozvíjel. Učitel je modelovým vzorem kritické, tvořivé a angažované osobnosti. Učitel a jeho osobní život, odrážející se v jeho hodnotové orientaci a komplexnosti jeho osobnosti, v jednotě slov a činů, v duchu klasického „Exempla trahunt“ hraje klíčovou roli. Pedagogické ctnosti učitele představují pedagogickou lásku, moudrost, odvahu a důvěryhodnost. ${ }^{27}$

S. Štech vypracoval tři alternativní modely učitele jako metafory učitelství - model „dělníka“, „řemeslníka“ a „umělce“. ${ }^{28}$ Model „dělníka“ je spjat s plánováním (napřr. cílových kompetencí), kvantitou pracovních úkolů (např. administrativní a vedlejší činnosti) a kontrolou jakosti standardu (kontrola učiva, učebnic, didaktiky, hodnocení apod.). U modelu „řemeslníka“ není výkon práce standardizovaný, ale směřuje $\mathrm{k}$ individualizovanému produktu. Práci vykonává relativně autonomním způsobem a není výrazně kontrolován zvnějšku. V tomto případě převládá zkušenostní poznání opírající se silně o praxi. U modelu „umělce“ stojí v popředí osobnost učitele, její citlivost a kreativita. Základem je vyjádření autentické zkušenosti učitele jako osoby a svobodná tvưrčí činnost. Kladou-li první dva modely důraz na dělání, model „umělce“ reprezentuje autenticitu bytí. V pedagogické praxi pak každý učitel kombinuje prvky těchto tří modelů a z tohoto pohledu se učitelská profese jeví jako smíšená (hybridní), tj. více náchylná k syndromu vyhoření. Učitel by měl zároveň pro žáka ztělesňovat přesah a motivovat jej k němu. Pro edukaci obratu představuje transcendování nový podnět. Znamená opuštění egocentričnosti a přesáhnutí svého Já směrem k určitému cíli, subjektu nebo objektu, a to může mít nejen edukační, ale i terapeutický účinek. ${ }^{29}$ Současné postavení učitelské profese v éře postmoderního vzdělávání je složité, nebot naplňování smyslu profesního bytí učitelů ovlivňuje nevyváženost pohledů společnosti i samotných učitelů na učitelskou profesní identitu. Na jedné straně si učitelé opakovaně stěžují na nedostatek respektu a ocenění, na dlouhodobé podfinancování, potýkají s neustálými změnami (změna školského zákona, kariérní řád, reforma financování regionálního školství), nárůstem administrativy, výchovných problémů žáků i problémů s rodiči; na druhé straně průzkumy ukazují, že učitelé patří mezi vážené profese, které se opakovaně umistují na předních místech společenského žebříčku profesí.

Současné podoby učitelství se dají vnímat trojím prizmatem - učitelství jako zaměstnání, učitel-

23 Srov. Vladimíra SPILKOVÁ - Anna TOMKOVÁ a kol., Kvalita učitele a profesní standard, Praha: PF UK, 2010, s. 22.

24 Tamtéž, s. 37.

25 Srov. HELUS - BRAVENÁ - FRANCLOVÁ, Perspektivy učitelství, s. 124.

26 Srov. ŠTECH, Profese učitele, s. 2.

27 Srov. HELUS - BRAVENÁ - FRANCLOVÁ, Perspektivy učitelství, s. 41-42.

28 Srov. ŠTECH, Profese učitele, s. 4-5.

29 Srov. HELUS, BRAVENÁ - FRANCLOVÁ, Perspektivy učitelství, s. 49. 
ství jako povolání, poslání a učitelství jako profese. Nelze hovořit o jediné dominantní podobě, spíše o nevyrovnané konvergenci typů pojetí. Základem je profesionalizace, profesní fundovanost oboru, o níž se intenzivně hovoří především ve spojení s kariérním řádem. V dnešní době je třeba více zdůrazňovat pojetí učitelství jako povolání-poslání (nikoliv pouhé zaměstnání) s návratem $\mathrm{k}$ archetypálnímu pojetí učitele jako rozvinuté osobnosti, které podle Z. Heluse zahrnuje nejen pedagogickou lásku, ale i pedagogickou moudrost, pedagogickou odvahu a pedagogickou důvěryhodnost..$^{30}$ Názory na vymezení učitelství jako profese nejsou jednotné ani mezi odborníky. Vl. Spilková, která srovnávala současný stav profesionalizace učitelství v řadě vyspělých zemí se situací v České republice, dospěla k závěru, že u nás učitelství stále setrvává spiše na úrovni semiprofese, respektive $\mathrm{v}$ mnoha aspektech směřuje $\mathrm{k}$ deprofesionalizaci. Vysvětluje to tím, že nejsou naplněny klíčové znaky skutečné profese - neexistuje profesní standard, etický kodex, profesní komora. Nedostatečná je také míra vnitřně přijaté profesní autonomie a profesní odpovědnosti u většiny učitelů. Učitelé po mnoho let pracovali v podmínkách modelu tzv. omezené profesionality v převládajícím pojetí učitelství jako zaměstnání, kdy byli chápáni jako vykonavatelé, realizátoři, spotřebitelé kurikula s minimální profesní autonomií. Spilková dále odkazuje na nepřipravenost velkého množství učitelů na nové požadavky vykonávání profese, spojené zejména s kurikulární reformou:

„Někteř́ autoři (Helus, Straková, Spilková...) hovoří o krizi učitelství, o učitelích jako slabém článku transformačních změn, o jejich neschopnosti vyrovnat se s novými nároky, o neochotě opustit stereotypy v práci, učit se nové věci, angažovat se v dlouhodobém procesu vlastní proměny s proměnou školy. ${ }^{31}$

Přikláníme se k tendenci rozvoje profesní způsobilosti učitele v duchu konstruktivistických a personalistických modelů, kde se hovoří o profesních modelech učitele reflektujícího profesionála, učitele-výzkumníka a učitele-experta. ${ }^{32}$ Učitel jako reflektující profesionál kontroluje a hodnotí vlastní pedagogickou praxi, pracuje na utváření svého profesního Já; učitel-výzkumník zkoumá pojetí vlastní práce výzkumným procesem, tj. rozvijí profesní hodnoty, vědění i praxi, a učitel-expert je profesním modelem, který spojuje schopnosti předchozích dvou kategorií na vysoké úrovni. ${ }^{33}$ Časem se prokáže, zda fenomén kariérního rádu přispěje k rozvoji náročné učitelské profese jako plnohodnotné expertní profese ve společnosti 21. století.

Učitelská profese je dnes profesí zátěžovou, nezabezpečenou, dokonce atakovanou. ${ }^{34} \mathrm{Na}$ učitele se kladou stále nové a nové nároky, např. integrace znevýhodněných dětí (sociálně, psychologicky, fyzicky aj.), integrace žáků se specifickými vzdělávacími potřebami a dětí z odlišných kultur; prevence šikany a sociálně patologických jevů; zavádění nových technologií, nekázeň, práce s nadanými a talentovanými žáky. Učitelé zažívají časté změny vzdělávacích projektů a organizace školy, jsou svědky nekoncepčností v řízení resortu (nap̌r. od roku 1993 do 2016 se vystřídalo v čele resortu 16 ministrů školství), zažívají netečnost vyšších školských úřadů. Učitelé jsou vystavováni $\mathrm{z}$ různých stran a důvodů kritice a výhradám. Rodina, veřejnost, společnost si do nich často pro-

30 Srov. tamtéž, s. 41-42.

31 Vladimíra SPILKOVÁ, Přístupy české vzdělávací politiky po roce 1989: Deprofesionalizace učitelství a učitelského vzdělávání?, Pedagogika 4/2016, s. 370-371.

32 Srov. Jitka LORENZOVÁ, Kontexty vzdělávání v postmoderní situaci, Praha: FF Univerzity Karlovy v Praze, 2016, s. 278.

33 Tamtéž, s. 278-280.

34 Srov. HELUS - BRAVENÁ - FRANCLOVÁ, Perspektivy učitelství, s. 5. 
mítají svá vlastní selhání. ${ }^{35}$ Bývají ve větší míře ohroženi kyberšikanou. Často vnímají svoji profesi jako společností nedoceňovanou. Chybí motivace pro profesní rozvoj učitelů, neuspokojená potřeba seberealizace mnohdy vede $\mathrm{k}$ frustraci. Chybí možnost kariérního postupu. Neexistuje plnohodnotný kariérní řád jako důležitý prvek profesionalizace učitelského povolání. Učitelské povolání je často spojeno se vznikem konfliktních, frustrujících až stresových situací. Učitel je po většinu pracovní doby ve styku s mnoha lidmi. Je neustále sledován a kontrolován. Profese je spojena s vysokým časovým zatížením a pracovním přetěžováním. Povolání učitele se vyskytuje $\mathrm{v}$ přehledu povolání ohrožených syndromem vyhoření na jednom z předních míst.

\section{Výzkumné šetření - prrípadové studie v rodině}

Pro účely předložené studie byl zvolen jiný postup, než byl použit u existujících empirických studií. Převážná část těchto studií se zaměřuje především na kvantitativní výzkum zjištování míry přítomnosti syndromu vyhoření učitelů na vybraných školách či škole; v našem př́padě jde o kvalitativní výzkum, který používá nejen kvalitativního, ale i kvantitativního výzkumného nástroje. Usilovali jsme tedy o zjištění aktuálního stavu přítomnosti syndromu vyhoření a jeho míry u tří vyučujících $\mathrm{z}$ různých stupňů škol ze stejného rodinného kontextu u jednotlivých generací (zaměřili jsme se na dvě generace). Rodina byla předem pečlivě vytipována. Kvantitativní šetření spočívalo v zadání a vyhodnocení čtyř standardizovaných dotazníků, jejichž cílem bylo zjistit míru zatížení organismu stresem ${ }^{36}$, míru emočního zatížení ${ }^{37}$, míru nebezpečísyndromu vyhoření ${ }^{38}$ a míru psychického vyhoření ${ }^{39}$. Usilovali jsme tedy o zjištění aktuálního stavu zatížení organismu a míry náchylnosti ke stresu a syndromu vyhoření u tří vyučujících z různých stupňủ škol. Samotné vypracování dotazníků zabralo respondentkám průměrně jednu hodinu; vyhodnocení dotazníků bylo provedeno podle daných kritérií. Cílem kvalitativního šetření bylo proniknout hlouběji do problematiky propojení míry zatížení organismu stresem a syndromem vyhoření ve spojení s individuálními „profesními a osobními příběhy“ vybraného vzorku pedagožek, $v$ němž je patrný různorodý vliv vnějších a vnitřních rizikových faktorů, které vedou ke vzniku a rozvoji syndromu vyhoření. Kvalitativní výzkum, který byl realizován prostřednictvím strukturovaného rozhovoru s otevřenými otázkami, trval průměrně 30-40 minut. Byl doplňován průběžným zapisováním poznámek do záznamového archu a audiozáznamem. Z těchto podkladů byly poté vytvořeny tři případové studie.

Výzkumný vzorek byl vybrán záměrně; proces vytipování cílové skupiny byl dlouhodobější, protože záměrem bylo sehnat vzorek pro vícegenerační výzkumnou sondu. Podařilo se zajistit dvougenerační výzkumný vzorek, v němž figurují matka-učitelka a dvě dcery-učitelky. U vícegeneračního šetření nás také zajímalo, zda se nějak odrazí případná zkušenost matky-učitelky se stresem a syndromem vyhoření v profesním chování jejích dcer-učitelek. Předem bylo zjištěno, že členky výzkumného vzorku si zachovaly pozitivní vztah k profesi, vyučování je baví či bavilo a jsou či byly ve své pozici uznávány. Jedná se o 3 vyučující z různých stupňů škol - ze základní školy (matka - učitelka Anna), střední školy (dcera - učitelka Tereza) a vysoké školy (dcera - učitelka Zuzana) s rozdílnou délkou pedagogické praxe, která se pohybuje v rozmezí 23-36 let. Kaž-

35 Tamtéž, s. 49.

36 Srov. Václav HOLEČEK, Psychologie v učitelské praxi, Praha: Grada, 2014, s. 192-193.

37 Srov. Thomas POSCHKAMP, Vyhoření. Rozpoznání, léćba, prevence, Praha: Albatros Media, 2014, s. 51-52.

38 Srov. HOLEČEK, Psychologie..., s. 194-195.

39 Dotazník míry psychického vyhoření (BM) autorů Ayala M. Pines a Elliot Aronson sleduje tř̌i aspekty vyčerpání: pocity fyzického vyčerpání, emocionálního a psychického vyčerpání. Vypočítaná hodnota BQ je hodnotou psychického vyhoření daného člověka. Srov. KřIVOHLAVÝ, Hořet..., s. 49-52. 
dá vyučující nejprve vyplnila čtyři písemné dotazníky, následoval polostrukturovaný rozhovor s každou zvlášt.

Pro větší přehlednost jsme výsledky standardizovaných dotazníků umístili do tabulek:

Dotazník náchylnosti ke stresu:

\begin{tabular}{|llll|}
\hline & učitelka Anna & učitelka Tereza & učitelka Zuzana \\
důsledky stresu & střední & nízká & vysoká \\
v oblasti kognitivní & $(12)$ & $(10)$ & $(22)$ \\
důsledky stresu & vysoká & střední & vysoká \\
v oblasti citové & $(18)$ & $(14)$ & $(20)$ \\
důsledky stresu & vysoká & vysoká & vysoká \\
v oblasti tělesné & $(27)$ & $(21)$ & $(22)$ \\
důsledky stresu & střední & nízká & střední \\
v oblasti sociální & $(14)$ & $(10)$ & $(15)$ \\
\hline
\end{tabular}

Nejvýraznější náchylnost ke stresu vykazovala vysokoškolská pedagožka Zuzana v oblasti kognitivní (dosáhla nejvyšší hodnoty ze všech tří respondentek), dále v rovině tělesné a citové; učitelka Anna ze ZŠ uvedla nejvyšší pocitované důsledky stresu především v oblasti tělesné (dosáhla absolutně nejvyšší hodnoty ze zkoumaných oblastí) a dále v rovině citové. Vysoká míra důsledku stresu v oblasti tělesné je patrná i u středoškolské profesorky Terezy. Je zřejmé, že důsledky stresu v oblasti tělesné jsou respondentkami subjektivně vnímány intenzivněji než důsledky v oblasti citové. Za překvapující lze označit vysokou míru stresu v oblasti kognitivní u učitelky Zuzany z VŠ.

Dotazník emočního zatižení

\begin{tabular}{|llll|}
\hline & učitelka Anna & učitelka Tereza & učitelka Zuzana \\
emoční vyčerpání & vysoké $(3,7)$ & střední $(2,44)$ & vysoké $(4,1)$ \\
$\begin{array}{l}\text { odosobnění / cyni- } \\
\text { smus }\end{array}$ & střední $(1,4)$ & nízké $(0,2)$ & nízké $(0,6)$ \\
$\begin{array}{l}\text { snížení výkonnosti } \\
\text { vysoké }(4,5)\end{array}$ & vysoké $(5)$ & střední $(4)$ \\
\hline
\end{tabular}

Dotazník emočního zatížení reaguje na individuální rysy osobností respondentek. Nejvyšší míru emočního vyčerpání uvedla vysokoškolská učitelka Zuzana, mírně snížené míry zatížení dosáhla také pedagožka ze ZŠ. Nejvýraznější hodnoty míry odosobnění (cynismu) prokázala učitelka Anna ze ZŠ. Všechny tři respondentky pocitují snížení pracovní výkonnosti (vyskytují se zde vysoké míry u vyučující ze ZŠ a SŠ).

Dotazník nebezpečí syndromu vyhorení

\begin{tabular}{|ll|}
\hline učitelka Anna & střední (146 bodů) \\
učitelka Tereza & střední (158 bodů) \\
\hline učitelka Zuzana & střední (154 bodů) \\
\hline
\end{tabular}


Všechny učitelky se v dotazníku míry nebezpečí syndromu vyhoření pohybovaly v pásmu středním s max. rozdílem 12 bodů.

Dotazník syndromu vyhoření (hodnota míry ohrožení BQ)

\begin{tabular}{|ll|}
\hline $\begin{array}{l}\text { učitelka Anna } \\
\text { učitelka Tereza }\end{array}$ & $\mathrm{BQ}=3,4$ zamyslet se nad životem a prací, stylem a smysluplností života \\
učitelka Zuzana & $\mathrm{BQ}=2,2$ uspokojivý stav \\
(u hodnot $=4,0$ až 4,9 je přitomnost syndromu vyhoření již prokázána)
\end{tabular}

Při hodnocení míry ohrožení syndromem vyhoření se pouze středoškolská vyučující Tereza pohybovala v rozmezí uspokojivého stavu. U učitelky Anny ze ZŠ byla zjištěna hodnota blížící se k hranici výskytu syndromu a bylo jí doporučeno, aby změnila svůj pracovní a životní styl. U vysokoškolské pedagožky Zuzany lze již konstatovat nástup syndromu vyhoření.

Z následujících strukturovaných rozhovorů byly posléze sestaveny tři případové studie, jejichž cílem bylo prohloubit rozpoznání nástupu a pochopení procesu rozvoje stresu a syndromu vyhoření u participantek. Riziko přetížení a vyčerpání v učitelské profesi je vysoké. I naše dílčí kvantitativní sonda dokládá, že náchylnost $\mathrm{k}$ syndromu vyhoření je př́ítomnou realitou u všech respondentek. Než přistoupíme ke komparaci a následnému popisu možných preventivních a terapeutických možností, musíme se seznámit s jednotlivými kazuistikami:

\section{Anna}

Učitelka Anna celoživotně působila v základním vzdělávání, odpracovala zde 36 let. Nejprve pracovala na venkovské ZŠ, po pěti letech odešla na městskou ZŠ, kde vyučovala až do odchodu do důchodu. Po celou dobu své pedagogické kariéry vyučovala český jazyk a další dva cizí jazyky. Přestože neměla žádné ambice stoupat po služebním žebříčku, zastávala pozice okresní metodičky a vedoucí předmětové komise, vedla různé kroužky. Učitelské povolání si zvolila cíleně, chtěla pracovat s dětmi, vychovávat je a předávat jim své životní ideály. Nepocházela $\mathrm{z}$ učitelské rodiny. Ve své práci byla vnímavá, chápavá, svědomitá a vytrvalá. $\mathrm{O}$ osud svých žáků projevovala zájem i mimo vyučování. Na konci své učitelské dráhy počítala týdny a dny, které jí zbývaly do odchodu do penze, protože se cítila silně vyčerpaná a unavená.

Vedle péče o rodinu (manžela a tři děti) nacházela čas i pro své zájmy (především ruční práce a četbu). V zaměstnání patřila mezi aktivní členky učitelského sboru. Vedením školy byla vnímána jako vyučující nadmíru pečlivá a zodpovědná. Vztahy s kolegy byly běžné. Během vykonávání učitelské profese se postupně cítila $\mathrm{v}$ jistých obdobích výrazně psychicky a fyzicky unavená až vyčerpaná, občas bývala nemocná a zjištovala, že v těchto etapách ztrácela do jisté míry zájem o své povolání, které zprvu vnímala jako poslání. Fáze únavy a vyčerpání se objevovaly s narůstajícím věkem častěji, ke konci profesní kariéry již nejen na konci školního roku. Vlivem stresu se u Anny objevovaly nejvýrazněji problémy v oblasti fyzické (byla zjištěna vysoká zátěž - vysoký tlak, bolesti zad, bušení srdce, ztuhlost šíje a ramen, střevní potíže, nadměrná únava, nespavost a vyšší náchylnost $\mathrm{k}$ nemocem) a citové (vysoká zátěž - převládaly negativní emoce - netrpělivost, nervozita, skleslost, úzkost, deprese, potíže s odpočinkem, očekávání nemoci); střední zatížení se projevovalo v oblasti kognitivní (obtížná koncentrace na práci, ztráta pozornosti, zhoršení paměti, vyšší výskyt chyb a snížení schopnosti správně analyzovat a hodnotit) a v oblasti sociální 
(bez nadšení pro kontakt s druhými, bez nadšení v oblasti zájmů, sklon k podezírání, častější konflikty a problémy ve vztazích s lidmi). Přestože se problémy stupňovaly, nikdy neuvažovala o odchodu ze zaměstnání. K uvolnění psychického napětí a stresu určitě přispěl fakt, že Anna po mnoha letech strávených ve sborovně získala místo v kabinetě (ten sdílela s dalšími dvěma kolegy). Získání částečného soukromí mělo „osvěžující“ efekt. Emoční vyčerpání Anny se pohybuje na vysoké hodnotě, v oblasti odosobnění/cynismu ve střední rovině a v oblasti výkonu je hodnota vysoká. Nebezpečí syndromu vyhoření bylo střední, hodnota míry ohrožení syndromem dosáhla hodnoty BQ 3,4.

Na zasloužený odpočinek se těšila, avšak nedokázala by si již představit, že by vyučovala soukromě, či krátkodobě zastupovala ve škole. Odchod do důchodu byl naplněn pocitem z dobře vykonané práce, což dokládá řada spokojených absolventů, kteří se opakovaně k učitelce Anně hlásí.

\section{Tereza}

Učitelka Tereza byla výbornou studentkou, která studium učitelství zakončila získáním červeného diplomu. První zklamání ze střetu s realitou nastalo hned při nástupu do zaměstnání, kdy měla nastoupit na ZŠ. Nabídky zůstat pracovat na VŠ nevyužila, protože chtěla vyučovat na SŠ. Nakonec nastoupila na jednu ze středních odborných škol, kde strávila zatím většinu svého profesního života (25 let). Posledních pět let vyučuje na gymnáziu. Její celková pedagogická praxe obnáší 30 let. Pochází z učitelské rodiny, vzorem se jí stala matka. Tereza chtěla být učitelkou již od dětství, profesi si zvolila sama a rodiče s ní souhlasili s tím, že se pro ni hodí. Nikdy o své volbě nepochybovala, učitelství má „, krvi“, a to ani když nastalo první rozčarování po nástupu do praxe. Odmala byla velmi pracovitá, snaživá, spolehlivá a soběstačná. Rodiče jí nemuseli věnovat žádnou nadstandardní péči, protože byla velmi samostatná a oni se starali o jejího méně samostatného staršího sourozence. Snažila se, aby s ní rodiče neměli žádné starosti. Na obou školách, na kterých působila, by díky své perfektní odborné vybavenosti (trojaprobace s cizím jazykem) a osobním kvalitám měla úspěšně stoupat po služebním žebříčku. K tomu však nedošlo. Ředitelé obou škol si byli vědomi osobnostních a pracovních kvalit, a tak jí začali svěřovat stále zodpovědnější a náročnější pracovní úkoly. Stala se koordinátorkou ŠVP, řešitelkou několika projektů EU, odpovědnou garantkou spolupráce se zahraničím při výměně studentů a řady dalších činností. Tereza nejprve chápala intenzivní nárůst pracovních povinností jako kompliment, ale očekávala, že přijde náležité ocenění či pracovní postup. K tomu nedošlo. Časem se začala cítit přetížená, vyčerpaná a reagovala na své okolí podrážděně. Připadala si jako stroj - ráno odešla do zaměstnání, odučila své hodiny a suplování, plnila další povinnosti administrativního charakteru a povinnosti třídní učitelky, pak odešla rovnou domů, kde po žádném, případně velmi krátkém odpočinku, následovala několikahodinová příprava na výuku dalšího dne, oprava či příprava testů, příp. také řšení administrativy. Také víkendy pravidelně trávila ponořená především do pracovních povinností a odpočinku tak věnovala pouze minimum času. Na záliby jí nezbývalo mnoho volného času (především ráda čte), čas věnovala péči o domácnost a o manžela. Ve škole pocitovala a pocituje přetížení administrativou, rivalitu mezi kolegy (Tereza pracuje na prestižní střední škole), pocituje tlak zvyšujících se nároků v oblasti profesních kompetencí. Ráda a iniciativně se účastní DVPP, organizuje přednášky odborníků - díky absolvování tří studijních oborů má široký odborný záběr, snaží se udržovat v kontaktu s novinkami z oboru. Zastávala pozici uvádějící učitelky, přednášela kolegům o novinkách ve školství. Ráda pomáhá a radí studentům a zařizuje pro ně mnohé potřebné mimoškolní záležitosti. Studentské problémy výrazně prožívá a bere si je osobně. Je vysoce empatická. Dobu dovolené využívá k vlastnímu osobnostnímu rozvoji, načítá nové 
materiály, mnohdy v přesahu oborů, připravuje si nové předměty... Pomoc ostatním - studentům i kolegům - považuje za klíčovou. Přestože se mnohdy - většinou na konci pololetí a školního roku - cítí psychicky a fyzicky vyčerpaná, nikdy není vůči svému okolí lhostejná. Pracovní vyčerpání se u Terezy projevilo opakovaně formou nemocí, které zpočátku přecházela, protože měla pocit, že je nenahraditelná. Po zkušenostech s pobytem v nemocnici svůj postoj přehodnotila, i když občas má tendenci vplout do starých kolejí. Učitelské povolání chápe jako poslání, nikdy by neučila pouze pro peníze. O odchodu $\mathrm{z}$ učitelské profese uvažovala pouze jednou při přestupu na novou prestižní školu, $k d y$, ač začínala v pokročilejším věku, se dostala do pozice začínajícího učitele. I zde časem prokázala své kvality, ale zažívala pocity deprese a únavy a připadala si jakoby chycená do pasti nekonečného pracovního kolotoče. Odměnou jsou jí opakované úspěchy studentů v soutěžích i jejich úspěšné absolvování studia na vysokých školách. Studenti se za svou paní profesorkou rádi vracejí. Učitelka v důsledku stresu vykazovala vysoké zatížení především v oblasti tělesné (bolesti zad, bušení srdce, sucho v hrdle, ztuhlost šíje a ramenou, nadměrná únava, další psychosomatické problémy, nespavost a vyšší náchylnost k nemocem). V oblasti citové je její zatížení střední (přetrvávají u ní většinou negativní emoce, pocit neklidu, nervozity, skleslosti, rozmrzelosti, sklíčenosti, komplexy méněcennosti, úzkosti a obav z nemocí). Nižší úroveň byla zjištěna v oblasti kognitivní (obtížná koncentrace na práci, řešení problémů náhodným a nepředvídatelným způsobem, vyšší výskyt chyb a snížená schopnost správě analyzovat a hodnotit určitou situaci) a v oblasti sociální (chybí nadšení při kontaktu s druhými lidmi i pro pěstování zájmů, sklon k podezírání a obviňování druhých, častější konflikty a problémy ve vztazích s lidmi). Test emočního zatížení prokázal střední emoční vyčerpání, nízkou úroveň odosobnění/cynismu a vysoké zatížení v oblasti výkonnosti. Test nebezpečí syndromu vyhoření ukázal střední nebezpečí (158 bodů) a BQ hodnota syndromu vyhoření je 2,2, což značí uspokojivý stav. Tereza se zdá být relativně stabilizována, avšak musí uvědoměle dbát na zlepšení svého životního stylu, aby se časem neposunula blíže k syndromu vyhoření. Měla by usilovat o zachování, resp. zlepšení svého přístupu k sobě v rovině osobní i pracovní.

\section{Zuzana}

Po absolvování vysokoškolského studia získala místo vyučující na VŠ a její intenzivní studium tak nadále pokračovalo s cílem získat další akademické a vědecké hodnosti. Má pedagogickou praxi 23 let. O profesi učitelky snila již odmala, protože také Zuzana pocházela $\mathrm{z}$ učitelské rodiny a vzorem jí byla její sestra. Naučila se téměř neodpočívat, stále před ní byly další a další pracovní výzvy, které plnila ráda a ochotně. I Zuzana je cílevědomá, tvrdohlavá, ale i zodpovědná a spolehlivá. Také ona zažívala na pracovišti postupné navyšování pracovní zátěže do té míry, že se cítila absolutně vyčerpaná psychicky i fyzicky. I zde se jednalo o prestižní pracoviště, které přinášelo řadu nepř́ijemných až konfliktních situací mezi kolegy. $\mathrm{O}$ výběru svého povolání nikdy nepochybovala, a když musela svou profesi na krátký čas opustit, opět vydala spoustu energie a zapracovala na sobě, aby se k vysněné profesi opět dostala. To vše ji stálo mnoho sil a to nejen fyzických. Zuzana má sklony k workoholismu a perfekcionalismu, což jí dovedlo léty do situace, kdy se její organismus již definitivně vzbouřil a téměř zkolaboval. Tehdy si uvědomila, že nastala hraniční situace, kdy musí konečně začít více odpočívat, nepracovat pravidelně celé víkendy i v čase dovolených. Dovolenou bez pracovních povinností neměla již skoro dvě desetiletí. Snaží se odpočívat krátce každý den po práci, tak si krátkodobě zajistit přísun energie, avšak náročnost profese ji vyčerpává pravidelně vždy na konci každého semestru. Stavy úplného vyčerpání postupně vymizely, i tak se však občas náhle dostaví. Zdravotní problémy se také vracejí, zatím se ale vyšší nemocností ne- 
projevují. Zuzana je svobodná a bezdětná, stará se o starší rodiče. Na starosti má také rozsáhlou zahradu a dům, takže jde „z práce do práce“. Mezi její záliby patří práce na zahradě, procházky se psem, čtení, malování a ruční práce. Zuzana neodhaduje správně svou př́lišnou pracovní výkonnost, mnohdy ji plně nevnímá. Díky kolapsu si uvědomila, že musí výrazně změnit př́stup $\mathrm{k}$ sobě i ke své profesi, mnohdy se jí to daří, občas sklouzává do zajetých kolejí. Pokud je již silně vyčerpána, mívá problémy s komunikací i řešením pracovních povinností, začíná se u ní projevovat prokrastinace. Vše si plně uvědomuje, situaci se snaží řešit. Má naději, že se časem její stav zlepší a nenastane $\mathrm{u}$ ní plně rozvinutý syndrom vyhoření. $\mathrm{V}$ testu náchylnosti ke stresu Zuzana vykazuje vysoké zatížení v oblasti kognitivní, citové i tělesné. Osobnostní rovina je zachycena $\mathrm{v}$ rovině střední. Kognitivní oblast vykazuje problémy s koncentrací na práci, ztrátou pozornosti, zhoršení paměti, řešení problémů náhodným a nepředvídatelným způsobem, ve vyšším výskytu chyb při řešení problémů, než je obvyklé, a ve snížení schopnosti správně analyzovat a hodnotit určitou situaci. V citové oblasti převládají negativní emoce - netrpělivost, neklid, nervozita, skleslost, sklíčenost, ustrašenost, komplexy méněcennosti, úzkosti, deprese, potíže s psychickým a fyzickým odpočinkem, očekáváním nemocí a strachem z nich. Tělesná oblast obnáší u Zuzany vysoký krevní tlak, bolesti zad, bušení srdce, sucho v hrdle, pocení dlaní, nadměrnou únavu, až únavový syndrom, nespavost... V sociální oblasti se přetížení ze stresu občas projevuje zhoršením souvislého mluveného projevu, chybí nadšení pro kontakt s druhými a pro realizaci zájmů, pocituje sklon k podezírání a obviňování druhých, uvědomuje si častější konflikty a problémy ve vztazích s lidmi. Emoční vyčerpání vykazuje vysokou hodnotu 3,20, odosobnění/cynismus je na úrovni nízké a výkonnost na střední úrovni. Nebezpečí syndromu vyhoření bylo otestováno jako stř̌ední zátěž ( 154 bodů), kdy je ještě př́ležitost dát problémové oblasti do pořádku. Hodnota př́itomnosti syndromu vyhoření je v rámci zkoumaného vzorku u Zuzany nejvyšší, BQ má hodnotu 3,904 (př́tomnost syndromu vyhoření je prokázána od hodnoty 4,00). U Zuzany je doporučováno zamyslet se nad životem, životním stylem, prací a smysluplností života.

\section{Komparace}

Jak se prokázalo, ani jedna $\mathrm{z}$ vyučujících není dosud ve stádiu plně rozvinutého syndromu vyhoření, avšak mají $\mathrm{k}$ němu nakročeno. Z šetření vyplynulo, že proces vyhoření je dlouhodobý, pliživý a ve fázích probíhající proces, který s sebou nese symptomy fyzického, emocionálního či duševního rázu a změny v chování. Ve všech třech případech, zahrnutých do našeho šetření, se prokázalo stř̌ední nebezpečí ohrožení syndromem vyhoření ( $\mathrm{v}$ jednom $\mathrm{z}$ nich téměř $\mathrm{v}$ hraniční hodnotě pro jeho plný rozvoj). U zkoumaného vzorku, kam jsme cíleně zařadili také jedince z vysokoškolského prostředí, se postupně objevují všechny tři faktory syndromu: všechny učitelky se ve vysoké míre setkaly s emocionálním vyčerpáním, částečně s depersonalizací a s částečným snížením pracovní efektivity. Nejedná se u nich zatím o stav totálního vyčerpání, tj. vyzrálý burnout syndrom. Je však patrné, že je třeba jejich proces směřující $k$ vyhoření zpomalit a zastavit. Učitelská profese je „nebezpečná“ především přetěžováním distresem a emočním vyčerpáním, které se odráží v psychice učitele, $\mathrm{v}$ jeho zdravotním stavu a následně v chování.

Všechny účastnice výzkumného šetření chápou své povolání (i bývalé) jako poslání, které by nikdy nechtěly vyměnit za jiné (učitelka Zuzana se $\mathrm{k}$ vysněnému povolání vrátila). Patří spiše $\mathrm{k}$ introvertním osobnostem, které spojuje snaha o co nejprecizněji odvedenou práci, pocit zodpovědnosti až perfekcionismu. Ten se projevuje především u dcer - učitelek. Všechny mají silný vnitřní poháněcí mechanismus a vůli ve svém povolání dosáhnout výborných výsledkủ se svěřenými studenty. Všechny účastnice výzkumu jsou profesně plně adaptované (učitelka Anna je již v důcho- 
du) a zralé osobnosti. Stres a vyčerpání se projevuje nižším sebevědomím, nestabilní emoční rovnováhou, nepříliš dobře vnímanou pracovní a životní spokojeností. Mnohdy se cítí společensky izolované. U obou dcer - učitelek došlo v době nástupu do zaměstnání ke střetu vnitřních ideálů s realitou, který záhy překonaly. Nyní z pozice učitelek-expertů s již dostatečnými zkušenostmi mají přesto sklon přeceňovat své síly a díky psychické a fyzické únavě jsou tak ohroženy syndromem vyhoření. V zahraničních pramenech se hovoří o příznacích vyčerpání, únavy a apatičnosti $\mathrm{u}$ starších učitelů s mnohaletou praxí, což se v našem průzkumu potvrdilo. Přestože toto pojetí u nás vyvrací Kebza se Šolcovou ${ }^{40}$, kteří tvrdí, že syndrom vyhoření není nijak spojen s pohlavími nebo délkou praxe, naše výzkumná sonda s jejich stanoviskem nesouhlasí, stejně jako řada dříve uvedených kvalifikačních závěrečných prací. Např. Nesvadbová, ${ }^{41}$ která zkoumala míru náchylnosti k syndromu vyhoření mezi pedagogy základních a mateřských škol, prokázala vyšší míru psychosociální zátěže a míru syndromu vyhoření u pedagogů základních škol především v rovině citové a tělesné. Náš výzkum toto potvrdil také. Autorka dále dospěla k závěru, že u skupiny pedagogů s praxí mezi 21-30 lety je náchylnost k syndromu vyšší než u pedagogů s nižším či vyšším počtem let praxe. ${ }^{42} \mathrm{~V}$ našem výzkumu se tato hypotéza nepotvrdila.

K nástupu jednotlivých fází vyčerpání až syndromu vyhoření přispívají také vnější faktory. Na prvním místě zmiňme rodinu - náš výzkumný vzorek se potýkal s vysokým nasazením v oblasti rodinných a personálních vztahů (péče o rodinné příslušníky, nadměrné zatížení při péči o rodinné zázemí včetně zahrady...), kdy nezbývá mnoho času na relaxaci a trávení volného času. Některé kvalifikační práce ${ }^{43}$ prokázaly, že pocit přetěžování a přepracování pocitují spíše ženy než muži. Také pracovní prostředí a školní atmosféra přinášejí řadu stresorů - účastnice výzkumného šetření si stěžovaly na rostoucí administrativní zátěž povolání (neustálé legislativní změny a reformy českého školství), rostoucí nároky na učitele a jeho odpovědnosti za výchovu a vzdělávání žáků, emoční a časovou náročnost práce, rivalitu, přetížení, obavy ze snižující se demografické křivky, feminizaci školství, ale také na nedostatečnou vzájemnou spolupráci a motivaci, nedostatečné vzdělávání v oboru a nulovou supervizi... Zmínily také nedoceněné postavení učitelské profese a skutečnost, že do škol nenastupuje mladá generace učitelů... Stibůrkováa ${ }^{44}$ ve své závěrečné kvalifikační práci, v níž zkoumala míru syndromu vyhoření v sedmero školských zařízeních (stacionář pro ranou péči, mateřská škola, základní škola, střední odborná škola, gymnázium, vysoká škola a pedagogicko-psychologická poradna) poukázala na zajímavé momenty, že čím je vyšší stupeň vzdělávací instituce, tím je riziko syndromu vyhoření vyšší. V naší výzkumné sondě se to nepotvrdilo: na jedné straně je syndrom vyhoření přítomen u vysokoškolské pedagožky, ale vysoká míra ohrožení je také u učitelky ze ZŠ. Dále Stibůrková prokázala, že čím je vyšší vzdělání pedagogických pracovníků, tím se minimalizují projevy syndromu vyhoření. Tento moment z hlediska našeho výzkumu stojí za zamyšlení - zjistili jsme, že ani jedna z účastnic výzkumu nebyla během pregraduální vysokoškolské přípravy proškolena v problematice syndromu vyhoření; stejná situace nastává i v rámci dalšího vzdělávání pedagogických pracovníků v současnosti.

Jak se prokázalo, za velkou výhodu považují všechny účastnice výzkumu to, že si mohou své zkušenosti a problémy navzájem sdělovat v rodinném kruhu a mohou se poradit. Avšak z hlediska prevence syndromu vyhoření jsme nezaznamenali žádný výrazný preventivní dopad; matka své

40 Srov. Vladimír KEBZA, Iva ŠOLCOVÁ, Syndrom vyhoření, Praha: Geoprint, 2003.

41 Srov. Ilona NESVADBOVÁ, Syndrom vyhoření učitele, Univerzita Palackého v Olomouci, Filozofická fakulta, Katedra sociologie a andragogiky, 2013

42 Tamtéž, s. 49-50.

43 Srov. Lenka STIBU゚RKOVÁ, Syndrom vyhoření v učitelské profesi (diplomová práce), Brno: PF MU, 2007.

44 Srov. Tamtéž. 
dcery opakovaně upozorňuje na skutečnost, že nemohou stále jenom pracovat a že musejí také zároveň intenzivně dbát na relaxaci ve volném čase. Dcery s tím souhlasí, ale pod vlivem každodenní pracovní reality a kvůli svým charakterovým dispozicím svůj pracovní režim př́liš nemění.

\section{Prevence a intervenční techniky}

Jestliže syndrom vyhoření patří k oblastem zájmu především základního výzkumu, není tomu tak u terapeutických postupů. Ty by se měly stát systematicky cílem aplikovaného výzkumu. Preventivní a intervenční strategie u syndromu vyhoření lze rozdělit do dvou základních skupin ${ }^{45}$ - první náleží do roviny primární prevence, jež se zabývá vybranými aspekty prevence; a druhá do roviny zahrnující intervenční techniky, které lze rozdělit na strategie individuální, sociální a organizační. Individuální strategie se snaží snižit př́tomnost stresu, který je vyvolán řadou faktorů. Nejčastěji se dotýká organizace a restrukturalizace mimopracovního času (patří sem rozvoj dobrého fyzického stavu /duševní hygiena, dieta, pohyb/, sociální podpora /vztahy/, pozitivní náhled na život, poznání vlastních schopností, posilování sebedůvěry apod.). V edukačním prostředí se také využívají kognitivně-řídící a psychodynamické metody (např. kurz asertivity, trénování sociálních dovedností, techniky řešení problémů, skryté modelování, techniky sebekontroly, techniky poznání, zastavení negativního myšlení...) a metody zaměřené na tělesné cvičení (relaxační techniky, dechová cvičení, techniky meditace...). Skupinové techniky v podstatě odpovídají předchozím technikám s tím rozdílem, že se aplikují ve větším počtu účastníků v seminární formě. Vhodné jsou relaxační techniky, řešení problémů, debaty o důležitých problémech apod. Organizační strategie úzce souvisejí s dalším vzděláváním pedagogických pracovníků. Nejlepší úspěchy $v$ boji proti stresu a syndromu vyhoření se dají očekávat při kombinaci jednotlivých strategií, tj. individuálních, skupinových a organizačních. Učitelé by měli znát vlastní adaptační mechanismy, účinky stresu na lidský organismus, př́činy syndromu vyhoření a metody prevence a intervence. To jim umožní aktivně přistupovat $\mathrm{k}$ zátěžovým situacím profesním i osobním, využívat možností snižování stresu a potenciálu rozvoje vlastní osobnosti, jež bude profesně adaptabilní, spokojená a schopná bojovat se stresem a syndromem vyhoření. Křivohlavý a Pečenková považují za nejlepší prevenci „žít smysluplný život" v rovnováze stresorů a salutorů, ${ }^{46}$ Maroon klade důraz na samostatné uvědomění si problému, aktivní převzetí zodpovědnosti, jasné uvažování a rozvoj porozumění, nové poznatky ke zvládání a zlepšení strategií, ${ }^{47}$ Matoušek zdůrazňuje jasné poslání organizace, přesné metody a omezení administrativní zátěže ${ }^{48}$ Klenarová a Matějková odkazují na osobní prevenci v kombinaci s prevencí pracovní založenou na dobrých vztazích na pracovišti, ohodnocení za práci, kontrolním systému, supervizi atd., ${ }^{49}$ Lhotková, Šnýdrová a Tureckiová kladou důraz na dvě strategie - strategii zaměřenou na řešení problému a strategii zaměřenou na vyrovnání se s emocionálním stavem, ${ }^{50}$ Vávrová zdůrazňuje dobře fungující systém dalšího vzdělávání pracovníků především v oblasti měkkých dovedností a nabídka individuální a skupinové

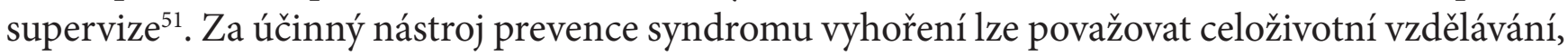

45 Srov. Eloísa GUERRERO BARONA, Jesús Carlos RUBIO JIMÉNEZ, Estrategias de prevención e intervención del Burnout en el ámbito educativo. Salud Mental, vol. 28, no. 5, octubre 2005, s. 29.

46 Srov. Jaro KŘIVOHLAVÝ, Jaroslava PEČENKOVÁ, Duševní hygiena zdravotní sestry, Praha: Grada, 2004, s. 28.

47 Srov.Istifan MAROON, Syndrom vyhoření u sociálních pracovníkư, Praha: Portál, 2012, s. 82.

48 Srov.Oldřich MATOUŠEK, Metody a řizení sociální práce, Praha: Portál, 2008, s. 58.

49 Srov. Jarmila KELNAROVÁ, Eva MATĚJKOVÁ, Psychologie 2. díl: pro studenty zdravotnických oborů, Praha: Grada, 2014 , s. 67.

50 Srov. Irena LHOTKOVÁ - Ivana ŠNÝDROVÁ - Michaela TURECKIOVÁ, Sebeřizení vedoucího pracovníka ve školství, Praha: Wolters Kluwer, 2013, s. 85.

51 Srov. Soňa VÁVROVÁ, Doprovázení s pomáhajících profesích, Praha: Portál, 2012, s. 126. 
které bude zaměřeno např. na schopnost efektivního plánování času nebo na zvládání psychické a fyzické zátěže $\mathrm{v}$ pracovním a osobním životě. Překonání syndromu vyhoření je obtížné, mnohem jednodušší je mu předcházet. Pokud nastane situace, kdy musí učiteli pomoci specialista, doporučuje se existenciální psychoterapie, daseinanalýza a logoterapie. ${ }^{52}$

\section{Závěr}

Svět, ve kterém žijeme, je informačně přesycený a zároveň lidsky podvyživený. Role pracovníků $\mathrm{v}$ pomáhajících profesích nabývá na stále větši významnosti. Vynořuje se dřive opomíjený spirituální rozměr života a služby člověku. Učitel je ten, kdo žáka vede a doprovází, ukazuje mu cestu i hranice, vysvětluje rozcestí. ${ }^{33}$ Pomáhá odemykat žákovský potenciál, je reprezentantem jeho naděje na vzdělání a naplněný život. Učitel by měl vykládat svět myslí a srdcem, umožňovat žákům stát se dospělými, svobodnými a odpovědnými. $V$ centru pozornosti stojí utváření celistvosti tělesně-psycho-sociálně-spirituální jednoty existence člověka. Nejvyšší triáda hodnot Pravdy, Dobra a Krásy zůstává věčnou výzvou. Podle Zd. Neubauera je vzdělání schopností zahlédnout zkušenost ve světle, které jsem nepřijal jenom zvenku, ale které jsem v sobě zrodil z toho nejlepšího, co ve mně je. To je výsostným úkolem učitele - zapálení ohně v žákově duši. Zapalovat oheň však nemůže ten, kdo je vyhořelý. Aby slepý nevedl slepého...

Syndrom vyhoření si zaslouží zvýšenou pozornost nejen u učitelské profese. Každým rokem začínají svou kariéru noví profesionální absolventi pomáhajících profesí. Je třeba včas preventivně zasahovat, aby se s bolestnou zkušeností syndromu vyhoření setkalo co nejmenší množství z nich. Na závěr ještě dovolte odlehčenější tón - podle NASA vyžaduje učitelské povolání podobné vlastnosti jako jsou kladeny na špičkové letce: „Učit ve škole je stejně náročné jako řídit raketoplán, ne-li těžší a nebezpečnějšsí “54. Z hlediska rozvoje syndromu vyhoření záleží nejen na osobnosti učitele, pracovním prostředí, mezilidských vztazích, př́stupu nadřízených a podpoře profesního rozvoje, ale i na rodinném prostředí, životním stylu a také na celospolečenské prestiži učitelské profese. Cílenou prevencí a strategiemi intervence ve školství by se měl výskyt syndromu vyhoření u učitelů, kteří představují jednu z nejrozšířenějších a nejstarších profesí v dějinách lidstva, omezit. Doufejme tedy, že písaře Bartlebyho potkáme v budoucnu v řadách svých kolegů jen zcela výjimečně.

2 Srov. GUERRERO BARONA - RUBIO JIMÉNEZ, Estrategias de prevención e intervención del Burnout en el ámbito educativo, s. 31.

53 Srov. HELUS - BRAVENÁ - FRANCLOVÁ, Perspektivy učitelství, s. 86.

54 HOLEČEK, Psychologie..., zadní strana knihy. 


\section{Učitel-profesionál jako písař Bartleby? Raděj ne! Syndrom vyhoření v učitelské profesi}

\section{Abstrakt}

Text se zamýšlí nad učitelskou profesí v 21. století jako konvergencí několika podob učitelství (zaměstnání, povolání, poslání a profese) a učitelem jako dělníkem, řemesIníkem či umělcem a reflektujícím profesionálem, výzkumníkem a expertem zároveň. Dále se soustřed'uje na multifaktoriální fenomén syndromu vyhoření jako významné psychosomatické poruchy učitelů.

Klíčová slova: učitelská profese, podoby učitelství, syndrom vyhoření

\section{Kontakt}

doc. PhDr. Helena Zbudilová, Ph.D.

Jihočeská univerzita v Českých Budějovicích

Teologická fakulta, Katedra pedagogiky

Kněžská 8, 37001 České Budějovice

hzbudilova@tf.jcu.cz 